\title{
APPLICATION OF SUPPLY CHAIN PERFORMANCE MEASUREMENT IN SCOR MODEL AT BUILDING PROJECT
}

\author{
Mochamad Agung Wibowo, Moh Nur Sholeh \\ Department of Civil Engineering, Faculty of Engineering, Diponegoro University, Indonesia \\ E-Mail: agungwibowo360@gmail.com
}

\begin{abstract}
The supply chain has become a priority subject of management research and manufacturing theory in recent years. It has also become an interesting topic in the construction industry. Construction supply chain management is more concerned with the coordination of discrete quantities of materials delivered to a specific construction project. Currently, in some building project, there has been no standard indicators in measuring the performance of the supply chain. Therefore, further research is needed to define the performance indicators there. One of supply chain performance measurement model is Supply Chain Operations Reference (SCOR). The SCOR model provides a unique framework that links performance metrics, processes, best practices, and people into a unified structure. The objective of the study is to define the application of SCOR in construction project. There are 11 Key Performance Indicator (KPI) on the SCOR model that could be used as an supply chain performance indicator in construction project. The research method of this study is by conducting a questionnaire to the project manager and material supplier to determine how the indicators are applied in building projects. The result of the study is the definition of each KPI at building project which facilitates understanding of construction stakeholders to measure the performance of the supply chain.
\end{abstract}

Key words: construction, supply chain, performance, SCOR, building project

\section{INTRODUCTION}

In recent years, the application of supply chain management (SCM) theory to the construction industry has been seriously investigated as an efficient and effective management strategy to improve the performance of construction [1]. As we know that construction industry has suffered from high fragmentation, poor productivity, large waste, time and cost overruns, conflict and dispute risk for a long time.

Supply chain management and collaboration have been used in many industries to gain a competitive advantage [2]. The philosophy has examples of successful applications through out the retail industry to the automotive and the agricultural industries. The construction industry has been relatively slow to use the concept of supply chain management due to the unique nature of the construction process and bespoke product with several stakeholders.

The high risks in the construction industry require monitoring on the construction site. The high variability of construction environments results in high construction cost variation, especially in material cost [3]. Inadequate planning may cause material shortages that delay the project schedule or a substantial increase in inventory costs by producing or supplying materials earlier than they are needed at the construction site.

The objective of the study is to define the application of SCOR in construction. Performance measurement of supply chain at construction project is useful in order to know the stakeholder capabilities. The stakeholder in construction is a contractor, subcontractor, owner, consultant design, consultant supervisor, and material supplier. Performance measurement of the supply chain of building project has not received much attention yet in academic literature [4]. One of the performance model in the supply chain is Supply Chain Operations Reference (SCOR) [5].

\section{LITERATURE REVIEW}

\section{Construction Supply Chain Management}

Construction supply chain management (CSCM) is an emerging area of practice. It is adopted by different substantials from manufacturing supply chain management, where the given priority is on modeling volume production. CSCM is more concerned with the coordination of the discrete quantities of materials delivered to the specific construction project.

The approaches of supply chain management have gradually been adopted by other industries [3]. When structuring a supply chain network, the supply chain partners are easily identified [6]. It will make the business function of enterprise more effective and efficient [7].

The modeling of construction supply chain management must be investigated to know how the construction concept in order to improve production efficiency and reduce project costs [8]. Supply chain management has four specific roles in construction [9]. First is to focus on the impacts of the supply chain on-site activities. Then, on the supply chain itself. In addition, the transferring activities from the site to earlier stages of the supply chain. Finally, the integration management and improvement of the supply chain and the site production.

\section{Performance Measurement}

Supply chain performance measurement is important to study and to practice in the construction industry. The main aim is to understand how the stakeholder manage the supply chain operations in the project [8]. The networking performance for a contractor in practicing construction management has been measured in previous research [10]. Five parameters are applied in the formation of the measurement model, including information exchange between project members, project communication system, knowledge-sharing for collaboration, corporate culture for promoting networking, and learning capability in Intra- and inter-organizational settings. The empirical results of this study enable contractors to realize what items determine the performance of interfirm networks, and what aspects of 
construction management practices should be emphasized to improve the networking performance effectively.

In another study, a model to quantify the impact of supply chain delays on the performance of a building project has been produced. This model provides an important measure of how supply chain delays may impact on project performance. It suggests that problems related to the supply chain in construction are likely to generate significant disruption to the project [11]. Furthermore, the specific performance measurement in supply chain management is Supply Chain Operations Reference (SCOR) model which is often used in the manufacturing industry.

\section{Supply Chain Operations Reference (SCOR)}

The Supply Chain Operations Reference (SCOR) model provides a unique framework that links performance metrics, processes, best practices, and people into a unified structure. The framework will support communication between supply chain partners and enhances the effectiveness of supply chain management, technology, and related supply chain improvement activities [5].

The SCOR model supports supply chain improvement by aiding the capture of as-is current state from which desired to be future state can be derived. By speeding data collection, SCOR can make it much less time consuming for managers to find answers to basic questions about a supply chain performance factors that could contribute and initiate corrective actions. For example, consider Perfect Order Fulfillment. This metric provides a good indication of how well every facet of a supply chain: planning, sourcing, manufacturing, and delivery are tuned and coordinated to meet customers demand.

SCOR model has been integrated with software ARENA that provides the supply chain analyst with a comprehensive and dynamic tool [12]. The other study of SCOR was compared data from a value stream mapping that the company managers will use when deciding where to allocate production resources in the international production network [13].

\section{MATERIAL AND METHODS}

This study was conducted by adopting the SCOR model. Project selected as a case study is the construction building in company A in Indonesia. It was selected because it has a material procurement scheme. Material to be investigated is steel supplier which is one of the main materials in the building project of company A Indonesia.

There are two perspectives of a key performance indicator of SCOR model. The first perspective from the contractor and the second perspective from the material supplier. There are $11 \mathrm{KPI}$ in SCOR model which divided in two facing. KPI in customer facing consists of perfect order fulfillment, order fulfillment cycle time, upside supply chain flexibility, upside supply chain adaptability, downside supply chain adaptability, and overall value at risk. KPI in internal facing consists of supply chain management, the cost of goods sold, cash to cash to cycle time, return on supply chain fixed assets, and return on working capital. The key performance indicator structure by SCOR model is shown in Figure 1.

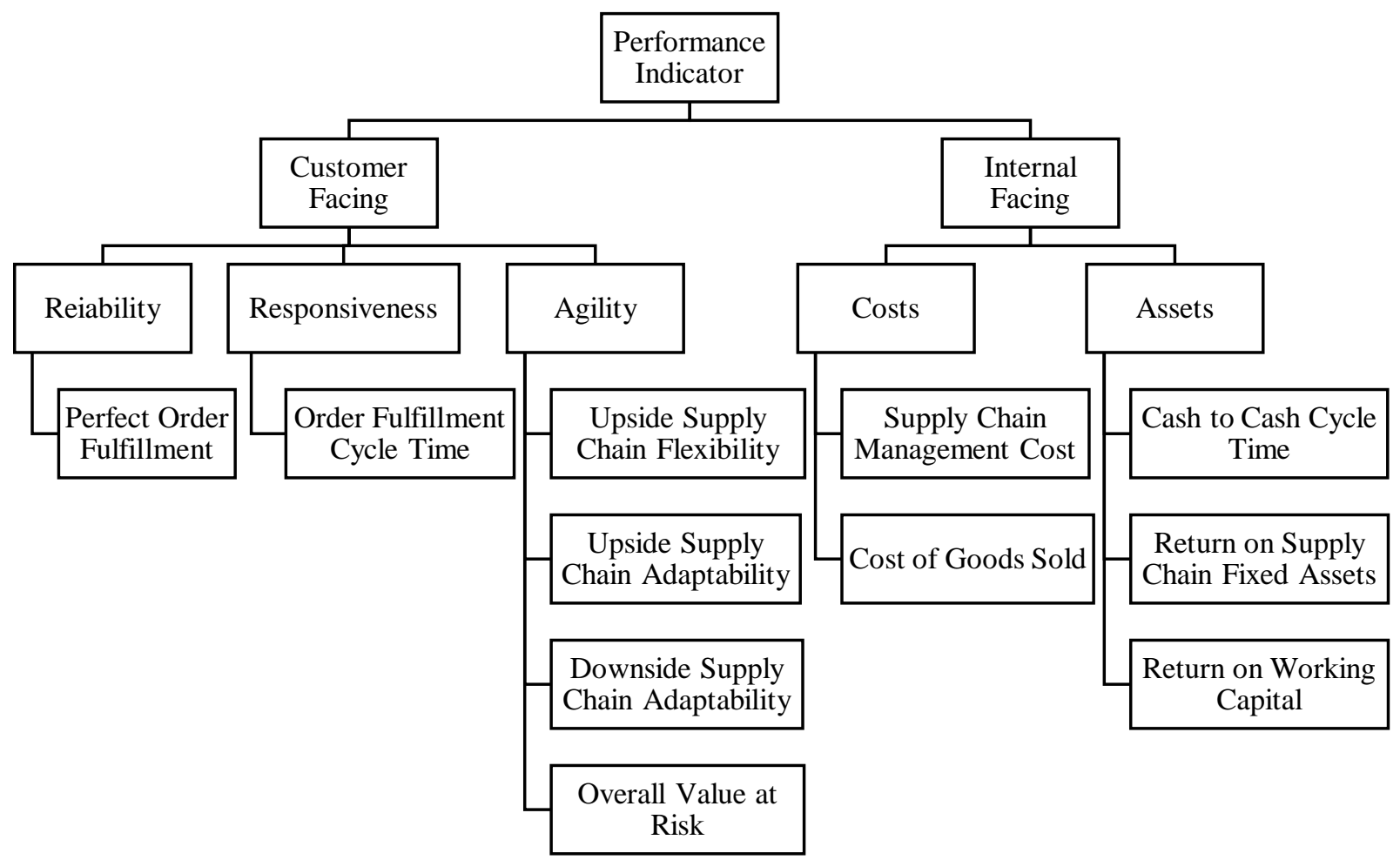

Figure-1 Key performance indicator structure [5] 


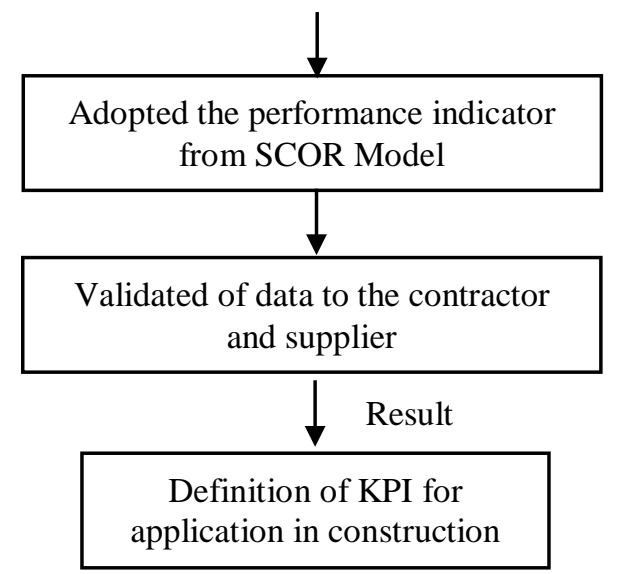

Figure-2 The step to make performance indicator framework
The steps of research in this study are shown in Figure 2. All 11 indicators are currently still in the definition of manufacturing. It needs to be defined more particularly in a construction application. These indicators are validated to the construction firm and a material supplier by conducting a questionnaire. Interview with the project manager in contruction firm and to the manager in material supplier. It explored the supply chain mechanism based on KPI in SCOR model. The results of interview and questionnares are in a qualitative statement.

\section{RESULTS AND DISCUSSION}

The results of the study are the definition of each KPI for application in construction project. Each KPI is explained in operational definition and application in construction project perspective. Key performance indicator by contractor perspective as Table 1 below.

Table-1 Key performance indicator by contractor perspective

\begin{tabular}{|c|c|c|c|}
\hline $\begin{array}{c}\text { Performance } \\
\text { Criteria }\end{array}$ & KPI & Performance Criteria & Application in Construction \\
\hline \multicolumn{4}{|l|}{ Customer Facing } \\
\hline 1. Reliability & $\begin{array}{l}\text { Perfect Order } \\
\text { Fulfillment }\end{array}$ & $\begin{array}{l}\text { The percentage of orders delivered, } \\
\text { delivery performance to customer } \\
\text { commit date, documentation } \\
\text { accuracy, and perfect condition. }\end{array}$ & $\begin{array}{l}\text { The percentage of fullfilment } \\
\text { material, documentation accuracy, } \\
\text { and perfect condition. }\end{array}$ \\
\hline 2. Responsiveness & $\begin{array}{l}\text { Order Fulfillment } \\
\text { Cycle Time }\end{array}$ & $\begin{array}{l}\text { The duration of source cycle time, } \\
\text { make cycle time, delivery cycle } \\
\text { time, and delivery retail cycle time. }\end{array}$ & $\begin{array}{l}\text { The duration of supplier for send } \\
\text { material to contractor since the date } \\
\text { of order material. }\end{array}$ \\
\hline \multirow[t]{4}{*}{ 3. Agility } & $\begin{array}{l}\text { Upside Supply } \\
\text { Chain Flexibility }\end{array}$ & $\begin{array}{l}\text { The company's ability to flexibly } \\
\text { against the number of days needed } \\
\text { to meet unplanned demand. }\end{array}$ & $\begin{array}{l}\text { The supplier's ability to flexibly } \\
\text { against the number of days needed } \\
\text { if contractor demand is change or } \\
\text { unplanned. }\end{array}$ \\
\hline & $\begin{array}{l}\text { Upside Supply } \\
\text { Chain Adaptability }\end{array}$ & $\begin{array}{l}\text { The company's ability to adapt a } \\
\text { maximum percentage of the number } \\
\text { of items that can be sent if there is } \\
\text { increased demand. }\end{array}$ & $\begin{array}{l}\text { The supplier's ability to adapt a } \\
\text { maximum percentage of the number } \\
\text { of items that can be sent if there is } \\
\text { increased demand from the } \\
\text { contractor. }\end{array}$ \\
\hline & $\begin{array}{l}\text { Downside Supply } \\
\text { Chain Adaptability }\end{array}$ & $\begin{array}{l}\text { The company's ability to adapt in } \\
\text { terms of percentage reduction in the } \\
\text { number of orders to be delivered in } \\
\text { the next few days. }\end{array}$ & $\begin{array}{l}\text { The supplier's ability to adapt in } \\
\text { terms of percentage reduction in the } \\
\text { number of orders to be delivered } \\
\text { when the contractor activities are } \\
\text { not much. }\end{array}$ \\
\hline & $\begin{array}{l}\text { Overall Value at } \\
\text { Risk }\end{array}$ & $\begin{array}{l}\text { The value of the risk borne by the } \\
\text { company as a whole. }\end{array}$ & $\begin{array}{l}\text { The value of the supplier risk when } \\
\text { there are an order or it send } \\
\text { materials. }\end{array}$ \\
\hline
\end{tabular}

There are 6 KPI in customer facing can be used to measure the supply chain performance. The each reason based on the contractor is:

1. Perfect order fulfillment

This KPI will help contractor to get the best quality in construction work based on the specification. If the order is perfect, it will reduce waste and keep good quality in a construction project. High KPI parameter indicates success.

\section{Order fulfillment cycle time}

The shorter the time or appropriateness planning will help contractor finish the work on time with minimum of delay. The low KPI parameter indicates success.

3. Upside supply chain flexibility

In a construction project, every material procurement based on the schedule. If there are changes of schedule, it will also effect the schedule of material procurement. If the supplier can flexible with the increased demand from the contractor, the contractor will trust the supplier. Besides that, it can do the work more convinced. Low KPI parameter indicates success.

4. Upside supply chain adaptability

If the supplier can adapt to the increased demand from the contractor, it shows the strenght in supply chain 
management. The KPI successful parameter is higher is better.

5. Downside supply chain adaptability

This KPI is similar to upside supply chain adaptability. If the supplier can adapt in terms of percentage reduction in the number of orders to be delivered when the contractor activities are less, it will help supply chain management of contractor. The contractor must maintain this relation. The KPI successful parameter is higher is better.

6. Overall value at risk
Construction supply chain management have many risks. The supplier must prepare every risk what could be accepted, transfered, or avoided. Therefore according to the contractor, the supplier must have a calculation to give the value of every risk. The KPI successful parameter is lower is better.

These KPIs directly could help contractor to measure the performance of supply chain of the supplier when related to the contractor. Meanwhile, the performance indicator by supplier perspective will be shown in Table-2.

Table-2 Key performance indicator from supplier perspective

\begin{tabular}{|c|c|c|c|}
\hline $\begin{array}{c}\text { Performance } \\
\text { Criteria }\end{array}$ & KPI & Operational Definition & Application in construction \\
\hline \multicolumn{4}{|l|}{ Internal Facing } \\
\hline \multirow[t]{2}{*}{ 1. Costs } & $\begin{array}{l}\text { Supply Chain } \\
\text { Management Cost }\end{array}$ & $\begin{array}{l}\text { The costs of overall supply } \\
\text { chain management (cost to plan, } \\
\text { cost to source, cost to make, } \\
\text { cost to deliver, cost to return, } \\
\text { and mitigation cost) }\end{array}$ & $\begin{array}{l}\text { The costs that are used by the supplier } \\
\text { to manage the supply chain of material. } \\
\text { It consists of cost to plan, cost to the } \\
\text { source, cost to make, cost to deliver, } \\
\text { cost to return, and mitigation cost. }\end{array}$ \\
\hline & Cost of goods sold & $\begin{array}{l}\text { The sale main costs that consist } \\
\text { of direct labor cost, direct } \\
\text { material cost, and indirect cost } \\
\text { related to production. }\end{array}$ & $\begin{array}{l}\text { The cost that be used by the supplier to } \\
\text { do supply chain management that } \\
\text { consists of direct labor cost, direct } \\
\text { material cost, and indirect cost related } \\
\text { to production. }\end{array}$ \\
\hline \multirow[t]{3}{*}{ 2. Assets } & $\begin{array}{l}\text { Cash-to-cash cycle } \\
\text { time }\end{array}$ & $\begin{array}{l}\text { The company cycle time to get } \\
\text { money that be an investment by } \\
\text { the company after buys raw } \\
\text { material. }\end{array}$ & $\begin{array}{l}\text { The supplier cycle time to get return } \\
\text { money after buys raw material to } \\
\text { produce materials. }\end{array}$ \\
\hline & $\begin{array}{l}\text { Return on Supply } \\
\text { Chain Fixed Assets }\end{array}$ & $\begin{array}{l}\text { The company return in fixed } \\
\text { assets such us tools or } \\
\text { technology information that is } \\
\text { used to production activity. }\end{array}$ & $\begin{array}{l}\text { The supplier return in fixed assets such } \\
\text { us tools or technology information that } \\
\text { is used to produce materials. }\end{array}$ \\
\hline & $\begin{array}{l}\text { Return on Working } \\
\text { Capital }\end{array}$ & $\begin{array}{l}\text { The company return from the } \\
\text { financial capital of work that is } \\
\text { used and also its profit. }\end{array}$ & $\begin{array}{l}\text { The supplier return from the financial } \\
\text { capital of work that is used and also its } \\
\text { profit. }\end{array}$ \\
\hline
\end{tabular}

There are 5 KPI in internal facing can be used to measure the supply chain performance. The each reason based on the supplier is:

1. Supply management cost

This KPI will help supplier to know the costs of overall of supply chain management. In each cost as the cost to plan, the cost to the source, the cost to make, cost to deliver, cost to return, and mitigation cost will be calculated in detail calculation. In repetitive production, the supplier will estimate the cost before producing the material. The KPI successful parameter is lower is better

2. Cost of goods sold

This KPI is very important to estimate the goods sold and the profit of supplier. It will be budget estimated reference to produce and sell off material. The KPI successful parameter is lower is better.

3. Cash to cash cycle time

This KPI will help supplier to manage the production of material or accept the order from contractor to get a return of money in short time. The KPI successful parameter is lower is better

4. Return on supply chain fixed assets
Not all production activities must rent or buy the tools. But if the supplier can buy tools for production, it will be benefit more for the next project or production. The KPI successful parameter is higher is better.

5. Return on working capital

This KPI will help supplier to know the return of working capital and profit. So, it can be used to measure the supplier activities in the supply chain. The KPI successful parameter is higher is better.

The results of performance indicator framework by Supply Chain Operations Reference (SCOR) model (Table 1 and Table 2) indicated SCOR model can be divided into 2 categories. The categories are customer facing and internal facing. Customer facing sees how the performance of supplier from the standpoint of the contractor. Therefore KPI as perfect order fulfillment, order fulfillment cycle time, upside supply chain flexibility, upside supply chain adaptability, downside supply chain adaptability, and overall value at risk are very fitting if analyzed from the contractor. While the internal facing sees how the supply chain performance of the company or in this case the supplier. Therefore KPI as supply chain management cost. The cost of goods sold, 
cash to cash cycle time, return on supply chain fixed assets, and return on working capital are very fitting if analyzed from the supplier.

There are two successful parameters of each KPI. The parameter are higher is better and lower is better. Higher is better will make contractor or supplier always increasing the score the KPI to get good supply chain performance. Meanwhile for the lower is better will make contractor or supplier always decreasing the score the KPI to get good supply chain performance.

Although every KPI can apply in construction supply chain and it has a successful parameter, but there are not a value of the measurement. There are three units of measurement as \%, days, and IDR or USD. The \% units are perfect order fulfillment, upside supply chain adaptability, downside supply chain adaptability, overall value at risk, return on supply chain fixed assets, and return on working capital. The day units are ordered fulfillment cycle time, upside supply chain flexibility, and cash to cash cycle time. While for IDR or USD units are supply chain management cost and cost of goods sold.

\section{CONCLUSIONS}

The overall results indicated that SCOR model can be adopted and applied in a construction project to define the supply chain performance. However, it must be defined in construction perspective in order to understand the SCOR model concept and to facilitate the contractor and material supplier. The results of study found 6 KPI as customer-facing that can be measured by customer or contractor. Moreover, 5 KPI can be measured by the supplier as internal facing. Adopting the performance indicator from SCOR model by defining and applicating in construction perspective. The next step is to validate data to the contractor and material supplier.

The study has several limitations. First, the case study just measures the performance indicator of one building project. It can be improved to adapt in other project sectors as roads, bridges, and damns. In addition, the material case studies only cope main material like steel and concrete. It can be developed in other materials. Finally, the respondents of the study is just one company that consists of contruction firm and materil supplier. The findings can be applied in other companies in order to know their supply chain management performnace.

\section{AKNOWLEDGEMENTS}

Author are grateful to the company A Indonesia and steel material supplier which have been a case study in this research.

\section{REFERENCES}

[1] X. Xue, X. Li, Q. Shen, and Y. Wang, "An agentbased framework for supply chain coordination in construction," vol. 14, pp. 413-430, 2005.

[2] A. Akintoye, G. Mcintosh, and E. Fitzgerald, "A survey of supply chain collaboration and management in the UK construction industry," vol. 6, 2000.

[3] H. P. Tserng, S. Y. L. Yin, and S. Li, "Developing a Resource Supply Chain Planning System for Construction Projects,” no. April, pp. 393-407, 2006.
[4] J. I. M. Halman and J. T. Voordijk, "Balanced Framework for Measuring Performance of Supply Chains in House Building,” no. December, 2012.

[5] Supply Chain Council, "Supply Chain Operations Reference Model,” Supply Chain Oper. Manag., pp. 1-976, 2012.

[6] H. Min and G. Zhou, "Supply chain modeling: past , present and future,” vol. 43, pp. 231-249, 2002.

[7] A. L. W. Ong and P. A. F. Ung, "Total quality management in the construction industry in Hong Kong : A supply chain management perspective," vol. 10, no. 2, pp. 199-209, 1999.

[8] M. A. Wibowo and M. Nur, "The analysis of supply chain performance measurement at construction project," Procedia Eng., vol. 125, pp. 25-31, 2015.

[9] R. Vrijhoef and L. Koskela, "The four roles of supply chain management in construction," vol. 6, pp. 169-178, 2000.

[10] C. C. W. Keung and L. Shen, "Measuring the Networking Performance for Contractors in Practicing Construction Management," no. October, pp. 400-406, 2013.

[11] J. Utomo, D. W. I. Hatmoko, and S. Scott, "Simulating the impact of supply chain management practice on the performance of medium-sized building projects," no. January, pp. 35-49, 2010.

[12] F. Persson and M. Araldi, "The development of a dynamic supply chain analysis tool - Integration of SCOR and discrete event simulation," Intern. J. Prod. Econ., vol. 121, no. 2, pp. 574-583, 2009.

[13] F. Persson, "SCOR template - A simulation based dynamic supply chain analysis tool," Int. J. Prod. Econ., vol. 131, no. 1, pp. 288-294, 2011. 